\title{
A role for the compulsory study of literature in accounting education
}

\author{
by \\ Roger Jeffrey Lister MA (Oxford) PhD FCA CTA \\ Visiting Professor, University of Salford, Salford M5 4WT. r.j.lister@salford.ac.uk \\ 01612955000
}

\begin{abstract}
Literature can make a multifaceted contribution to higher education especially in a highly vocational field of study like accounting. Such fields suffer particular pressure to impart 'marketable skills' in response to student demand, governments, and the professional bodies. Literature militates against the threat of 'de-disciplining'. Literature hones and enriches expression. It reinforces original, creative, imaginative and multicultural thought. By adding a disciplinary dimension, literature encourages reflective consideration of ideas in terms of the difference which they make to other ideas. Studied holistically literature sets important issues into the context of human endeavour and choices. Not least literature is prophetic. The labour market will, in the long run, penalise those who lack the qualities which can be uniquely imparted by literature.
\end{abstract}

Key words: accounting education literature 


\section{I: INTRODUCTION}

There are five main motivations for the present paper.

The first is the suggestion that cash-strapped universities are under ever increasing pressure from government and their own consumers to hawk 'marketable skills' (Graham 2005; Wolf 2007). Graham (2005, p. 186) makes the general case:

While it is understandable that those brought up in the traditions of one discipline should have special loyalties to that discipline, the cause of knowledge as such is better served by transcending residual loyalties and working across disciplines.

Bugliarello (2003) specifically argues that questions such as the probability, nature and severity of the side effects of technology cannot be addressed without the involvement of the humanities. Crawford (2006) illustrates how productively such links can be forged. The present paper asks one question. Can the arts - in particular literature - fuel qualities and increase direct insight into our field in ways which will make our graduates truly 'marketable' people and less impoverished human beings?

The second motivation for this paper is increased interest in reflective learning. Its advocates seek to recognise with Confucius that 'study without reflection is as waste of time; reflection without study is dangerous'. How does literature further this purpose?

The third stimulus is Mary Evans’ Killing thinking (2004). Evans identifies the danger of intellectual poverty inherent in vocational education: a threat of universities becoming at worst skills factories providing technical apprenticeships. Accounting and cognate schemes of study are particularly vulnerable to her concern. Imparting 'skills' is a task best left to institutions better equipped to provide the service leaving universities free to emphasise the stretching of intellects and empowering of imaginations with minimal box-ticking. 
The fourth motivation is the writer's unhappiness with Joseph Badaracco's recent Questions of character (2006b) and his responses to an interview in the Harvard business review (2006a). His finely informed work goes back as far as Sophocles’ Antigone and forward to the 20th century. Across time and cultures he identifies and sharply analyses examples of judgment in world literature. Despite the undoubted didactic power of his work it entails a truncated approach which is limited to one aspect of one facet of the literature which he examines. This is far less valuable than imparting each work to students as an aesthetic whole with leadership, judgement or whatever as an inseparable part of that whole. Time constraints can be accommodated by rigorous selection of microcosmic material.

The writer's fifth motivation comes from long term financial forecasting. Literature is prophetic. The $21^{\text {st }}$ century has witnessed new attempts to review and forecast long-term equity returns for decades and centuries past and ahead (e.g. Dimson, Marsh and Staunton (2002); Goetzmann, Ibbotson and Peng (2001)). It will be argued here that literature, whether in the form of individual works or movements, may be the first to pick up the scent of a zeitgeist.

The writer is not claiming academic high ground for literature over other arts disciplines. A zealous but narrow student of literature will be a foreshortened creature unable to set his thought into the context of the choices that society has to make. It is no coincidence that one of the greatest minds in European literature, Goethe (17491832), was an accomplished scientist and mining engineer. Far from being divorced from reality, poetry has been described as 'a reaction to what is contemporary and topical' (Weinstein 1995). However this may be, it will be argued that literature is particularly well suited to serve our purpose.

The following sections pursue the above five motivations and are entitled: II Case for literature; III Reflective learning; IV Crisis in higher education; V Whole use of literature; VI Literature as prophesy. Section VII addresses implementation. It is followed by the conclusion. 


\section{CASE FOR LITERATURE}

Literature is a deep well of experience for the social sciences. But it is more than this. By harnessing imagination, literature extends experience. It raises the heavens and deepens the hells of life. Literature achieves connections among the seemingly disparate, be it within literature itself, across the arts or across a wider range of disciplines. Many have challenged the assumption that literature operates differently from scientific thinking (e.g. Hayes 1984). It will be recalled that Albert Einstein said that 'imagination is more important than knowledge'.

A relevant contrast is between the 'useful' and 'valuable' disciplines (Graham 2005, p 181). The former help us 'to live longer healthier and more prosperous lives' while the latter 'make those longer, healthier lives worth living'. Graham assigns art, literature, music, philosophy and history to the latter category. The present argument is that literature serves both purposes and has particularly much to offer in accounting education.

\section{Ambiguity}

Why will literature produce better graduates in accounting and related disciplines? One reason is that our disciplines, with a view to organized decision-making, try to reduce ambiguity. Whether seeking to report structured financial instruments, to define the market portfolio or to address depreciation we tend to limit parameters. The aim is to provide managers with formulae for their objective, the cost of their capital or to express an asset or liability.

It is accepted that the need to live with uncertainty and ambiguity is very well acknowledged by accountants and that accounting and auditing standards are replete with references to the need for accountants to exercise their professional judgement and arrive at unbiased estimates. It is equally accepted that accountants recognise and strive to bridge the gap between economic reality and financial reporting. It is true that some aspects of financial reporting appear to convey information to the capital market. And it would be wrong to overlook the qualities of accounting's best thinkers, not least its a priori writers. They possess lucidity of expression, reasoning and 
intellectual breadth of a high order. As such they are a sine qua non for any student of our field. All educators and some students will have been exposed to the incisiveness and irony with which Sterling (1971) demolishes the traditional accounting framework after presentation of other approaches to measurement of business income.

At the same time the shortage of overall economic reality in a set of published accounts, partly due to the wish to eschew ambiguity, remains a matter of concern to our scholars and practitioners alike. The struggles to report derivatives meaningfully are an example, as are the numbers provided for co-existing credit derivatives, guarantees, finance leases, quoted loan stocks and other long-term liabilities. All too often what we report is a caricature of reality. For example the favoured definition of cost of capital - weighted average cost of capital - is unreal and impoverished. Lister (2007) has argued that 'we can't measure the parameters of any definition (of cost of capital) with useful accuracy. Attempts to adapt general cost of capital to the individual company and then to individual projects merely compound the unreality. If we seek wisdom in practice we find managers behaving in an untutored inconsistent and incomplete way’.

Progress will come from embracing ambiguity. As do our best colleagues already, we should imaginatively look into ambiguity's richness. Leading research in finance has never been shy about breaking down interdisciplinary barriers. It is sufficient to mention physics, neuroscience, cognitive psychology and a range of branches of mathematics. Tirole's definitive new textbook (2006) built around contracting is an open invitation to students to consider a more imaginative and complex set of incentives, covenants and signals.

It is true that skills including 'reflection' and tolerance for ambiguity can be developed via the incorporation of topics like ethics into course activities and proper use of case studies. More sophisticated course-members might be inspired in 'their own time' to pursue links among social accounting, poetry and ecology (Burnside 2006). Unarguably science, music and philosophy are part of the formation of the person. It is to be hoped that any course-member who had listened to Mozart's two 
minute long Allelulia would be that bit less inclined to reflect tritely and uncreatively. According to Holub (2006) it is the scientist-poet who perhaps best realises that:

Human communication should be economical, as condensed as possible, allowing the other party enough time and space to reach his or her own answers and conclusions. It was Ezra Pound who underscored the fact that poetry means condensation (German dichten means Latin condensare).

While accepting the intellectual qualities of accounting's best thinkers and accepting that other disciplines have much to offer, the present case is that literature is best fitted to make the contribution which we seek. Literature is a transcription of life into language but much more. Literature is memorable, provocative, sometimes iconoclastic, inspiring and widely accessible. As one of the most imaginative forms of expression it encourages our minds to range questioningly, creatively and originally. Literature harnesses and stretches to its painful and disconcerting ultimate the power of human imagination. Its artifice generates greater reality. Literature stretches our intellect, extends our reach and firms our orientation. If utilitarian justification is insisted upon, George Eliot (1819-1880), quoted by Wood (2008 p. 129), describes literature as 'a mode of amplifying experience and extending our contact with our fellowman beyond the bounds of our personal life'. In sum a definition of literature appropriate to the present context could be 'imaginative drama, narrative and poetic fiction'. At the same time literature itself crosses disciplines. Works such as the Divine comedy (1400) by Dante (1265-1321) are interdisciplinary Everests. Sensitive portrayal of character sits among mathematical complexity and ruthless political condemnation.

Whilst advocating literature as the most suitable vehicle for our purpose it is necessary to guard against any intellectual elitism - in plain words snobbery. Literature must feel free able to embrace film, television - even popular song. For example, the dangers of reification of people can fruitfully be debated using any of Plato's Republic (с 360 BC), Orwell's Animal farm (1945), and Nineteen eighty-four (1949), But at the same time Fritz Lang's film Metropolis (1927) provides food for 
thought in an increasingly technologically dependent age - e.g. what should be the role of The Mediator charged with reconciling interests and classes? This last could be used with the disturbingly prophetic Brave new world (1932) by Huxley (18941963).

Literature is replete with issues around drivers and exercise of power. The educator is spoilt for choice not least among the Prince (1513) of Machiavelli (1469-1498), the Leviathan (1660) of Hobbes (1588-1679), the Admirable Crichton (1902) of Barrie (1860-1937) and the Lord of the flies (1954) by Golding (1911-1993).

Machiavelli will resonate with course members who have some industrial experience. The prince seeks to thrive albeit surrounded by innate human malevolence and some may have been at the receiving end of tactics such as disarming, division and contrived animosity

The TV series Lost instils a state of inner reflection and reflective learning. Like millions of viewers, course-members would enjoy the intellectually liberating experience of debating matters including power, personal rebellion and the goal of humanity including the apocalypse. Tony Hancock’s TV work Missing page would duly demolish simplistic predispositions about 'truth', especially if studied in tandem with Sidney Lumet’s film 12 Angry Men (1957) which roots out the irrational, atavistic roots of a jury's so-called thought-out verdicts. Similarly there is a case for The Caucasian Chalk circle (1947), by Brecht (1898-1950) where 'judge’ Azdak dispenses equity in a brief golden age. The first part of Atonement (2001) by McEwan (1948-) is another interesting parallel with its false judgement of another's guilt.

It is sometimes stimulating to explicitly bridge the classical and the popular. Consider assertion. Prometheus (1774) a poem by Goethe (1749-1832) exalts man's heroic power. The same permeates Beethoven's music. But equally so do the songs of Edith Piaf (1915-1963) who performed the defiant Milord in 1959 to confound rumours that she was ill or even dead, and whose live performance of Je ne regrette rien (I regret nothing) in 1960 at the Paris Olympia is iconic. Great poets know already how to use the popular. Whitman (1819-1892) draws his metaphors from ordinary things 
of nature like grass and the noiseless patient spider. He lauds ordinary and voiceless people like the prostitutes, slaves and sick with whom he associated.

Literature, especially novels, widely addresses the collision between the individual and society. Already in medieval times we have Chrétien de Troyes (12 ${ }^{\text {th }}$ century) portraying the adventures of the knight Yvain in this sense. Challenges to authority through embracing moral ambiguity often meant great risk for the writers, for example the questionings of Soviet era writers in Russia, the artistic freedom asserted by Oscar Wilde (1854-1900), the bold assertion by Beaumarchais (1732-1799) through the character of Figaro of the rights of the ordinary people, and the indictment by Molière (1622-1673) of clerical hypocrisy in Tartuffe. It is significant that Figaro's name has been interpreted as a pun on Beaumarchais' own name ('fils Caron'). These classical writers were daring to anticipate the contempt of Wallace Stevens (1879-1955) for whom 'the only emperor is the emperor of ice-cream'. Able to write with greater freedom than his classical forbears Maupassant (1850-1893) thoroughly discredits the representatives of religion and virtue in comparison with a prostitute who sacrificed honour at their behest - only to be subsequently despised.

Literature with its multidimensional evocations and dissonances may explicitly set out to be ambiguous. Henri Coulet says of Manon Lescaut (1731) by Prévost (16971763) :

Manon Lescaut is a novel which is all the more intriguing because we can search it endlessly while remaining uncertain of its lessons.

The poem “Thirteen ways of looking at a blackbird” by Wallace Stevens (1879-1955) is an exercise in ambiguity. It epitomises the endless angles of vision on reality. The existential message of Stoppard's Rosencrantz and Guildenstern are dead (1964) uses language to convey bewildering ambiguity. 
In sum our course-members should take a break from trying to 'eliminate ambiguity' and give our minds free rein. If we read only one stanza of William Blake's Tyger (1794), Lord Butler and Mary Evans begin to make more sense:

Tyger, Tyger, burning bright In the forests of the night, What immortal hand or eye Could frame thy fearful symmetry?

Perhaps the extreme instance of 'ambiguity’ is French symbolist poetry which borders on music to the point that it has no visual 'programme'. It stimulates questioning and wonder and inculcates a love of and a respect for language. Its music would thoroughly discourage any student from writing clumsily and sloppily. Hear Chanson d'automne (1866) by Paul Verlaine (1844-1896):

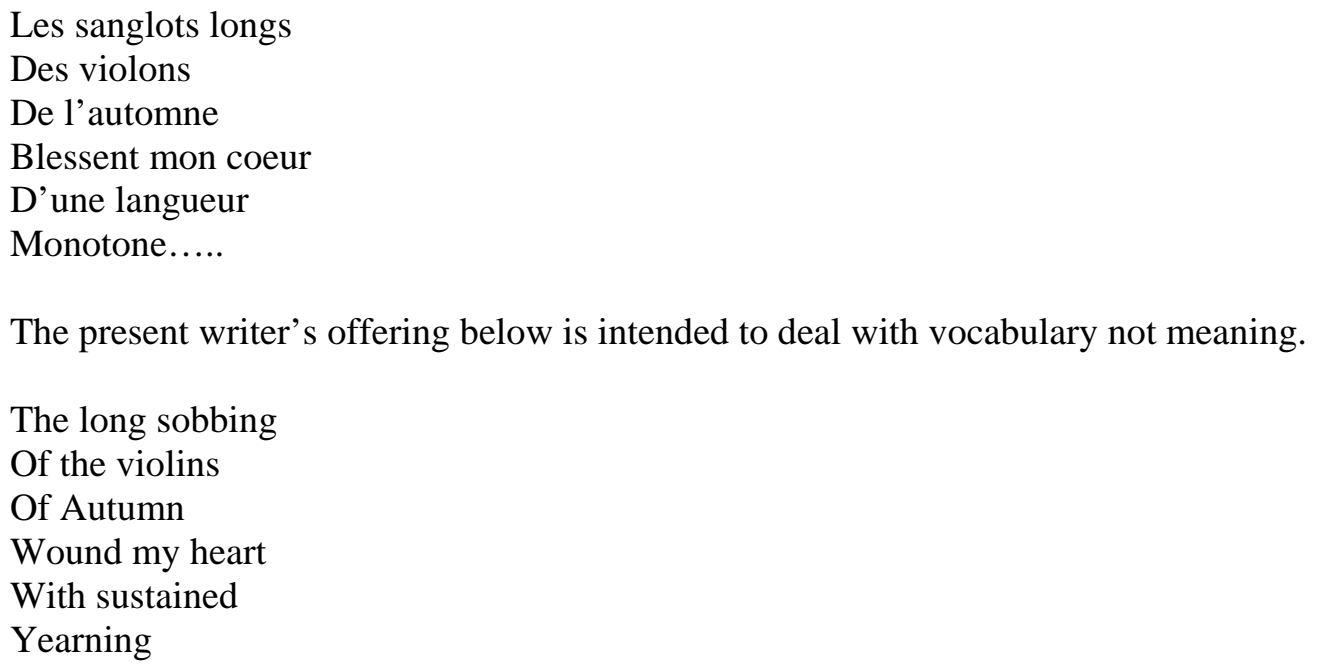

The music of Windhover (1877) by Gerard Manley Hopkins (1844-1889) shows how language can almost literally create experience. Knowing how to read it is a gift reserved to a minority. 
Ambiguity in literature often entails mould-breaking and iconoclasm, especially when moulds are broken to achieve self-realisation. The father by Strindberg (1849-1912) which appeared in 1887 prophetically portrayed the crumbling of moral values held sacred for millennia. The Choral symphony (1824) of Beethoven, using the words of Schiller (1759-1805), gives bourgeois morality a thorough shaking. He portrays the pious and the wicked (Alle Guten, alle Bösen), the lowest animals and highest celestial beings, all going forward, hand-in-hand, united in joy. Who is excluded, weeping? Certainly not the wicked: only he who has failed to secure a friend or conquer a beautiful woman. We are far from the European Court of Human Rights. With equal disregard for conventional morality Goethe's hero Faust at the end of the Second Part (finished about 1832, lines 11233-11281) burns down the home and chapel, and sacrifices the lives, of the aged Philemon and Baucis for the sake of consummate self-realisation. Course-members may recall this part of their literature module as they or their colleagues climb over others to success. A stark case of unrepentant moral ambiguity is the poem of less than two pages by Housman (18591936) entitled Hell gate (1922). Hell is destroyed, not by virtue or redemption, but by the poet's erstwhile partner in immorality.

Thomas Hardy (1840-1928) in Tess of the D'Urbervilles (1891) takes an unconventionally bitter view of providence. And the heroine of Lady Chatterley's lover (1928) by D.H.Lawrence (1885-1930) fulfils and understands herself by breaking down social barriers, including the exigencies of marriage to her crippled, impotent husband. For Lawrence, morality is a side- or non-issue in characters' quest for a perfect male-female relationship. The obscenity trial (1961) evoked, by way of defence, the opposition to all forms of censorship of the equally subversive Walt Whitman (1819-1892). And William Blake in his Marriage of heaven and hell (1793) is totally anti-clerical, overturning religious dogma and blaming it for the grossest immorality.

At the same time advocacy of morality in literature can be as ethically disturbing as literature's immorality or amorality. Charles Dickens (1812-1870) set out to shake up the complacent urban middle classes in a work like Great expectations (1860-1861) with its implicit critique of law and the city. His portrayal of a classless amoral world- 
order, permeated by unscrupulous quest for wealth which corrupts individuals in the process, will be familiar to those who have lived through the last decades of the twentieth century. The short story Bartleby (1853) by Melville (1819-1891) anticipates the reification of the individual in the modern work-place and sits well with Pynchon's Against the day (2006) with its story of unrestrained corporate greed, false religiosity, moronic fecklessness, and evil intent in high places. Le Carré (1931-) leaves the reader thoroughly morally bewildered in The spy who came in from the cold (1999).

Among the most morally challenging cases is the Satan of Paradise lost (1667) by Milton (1608-1674). Almost in spite of himself Milton turned the embodiment of evil into a leader who is a near tragic hero and who commands the reader's sympathy. Satan prefers to reign in hell tormented by his fall than serve in heaven. All our might-have beens, all our remorse are in Satan’s (line 619):

....thrice in spite of scorn

Tears, such as angels weep, burst forth.

Light years from accountancy? Far from it. Picture our students, refreshed by literature, directing critical and imaginative thoughts to conventional accounting. It is not surprising that some scholars consider the creation of new aesthetic forms to be the most productive human endeavour.

Literature is an art-form among others. Inspiration comes from all the arts. There is a history-long tradition of the fine arts enriching and carrying forward utilitarian fields. Wedgwood and Royal Doulton porcelain broke the chains of biedermeier with the help of contemporary fine artists. Music humanises therapy. Poetry, rhetoric and the classics enrich politics. It would furthermore be elitist and indeed patronising to assert that all our 'relevant' undergraduates and graduates start from a position of cultural penury. So why the present focus on literature? Firstly and incidentally, it is the field in which the writer was trained and is most familiar. Secondly and importantly, it is a particularly articulate and convenient vehicle for communicating 
and illustrating concepts. Students in our field would benefit from formal exposure as mature people to literature. This would be even more beneficial if they had already received a basis as young adolescents.

\section{Cultures}

We encourage our students to think globally about their future profession. In order to do this their thoughts will need to transcend international accounting standards, international asset pricing models, tax harmonisation and international economics. They will need to empathise with different cultures, corporate and national. Failure to do this has been a significant cause of merger failure (Gertsen, Søderberg, and Torp, 1998; Tienari, Søderberg, Holgersson and Vaara 2005). A country or region’s literature gives insight into character, thought-patterns, decision processes, zeitgeist and the very fabric of expression. This can only help us to anticipate and resolve destructive conflict. We might have been less inclined, as consultants, to propose totally unsuitable models for Russia and her neighbours if we had studied War and peace by Tolstoy (1817-1875) - as fresh and relevant today as in 1869. This work points up the country's ruthless unmanageable history. Facile imposition of westernstyle free choice was doomed to bring much of today's corruption and anarchy. Truly 'we understand the scope of our own day by delving into the sensibilities of other times and cultures' (Weinstein 1995). He characterises literature as ‘a cultural script which is unique'.

Literature is the ideal vehicle for studying prejudice in culture, and, within prejudice, tolerance. Universally known examples are Shakespeare's Othello and Merchant of Venice. But perhaps a particularly useful example is the Andorra (1961) of Max Frisch (1911-1981). This minutely examines the victim's reaction to prejudice and leads up to the mind-churning finding that he has been mis-identified as a member of the persecuted group. Ayckbourn's If I were you (2006) operates similarly by portraying the genders suddenly thrust into each other's role.

Tolerance mitigates destructive culture-clash. Two contrasting works are Nathan der Weise (Nathan the wise 1779) by Lessing (1729-1781) and Silbermann (1925) by 
Lacratelle (1888-1985). The former focuses on the philosophy of tolerance, the latter on the psychological and social aspects.

Popular and naïve literature as well as 'high' literature can serve our purpose. At an extreme Tzung-Yu Cheng in 1993 used children’s essays to examine linearity and circularity in Chinese thought-patterns. Schiller in his Über naive und sentimentalische Dichtung (Of naïve and sophisticated fiction) (1800) suggested that naïve fiction with its ‘edle Einfalt' (noble simplicity) could attain an intensity of expression beyond the reach of sophisticated works. Naively expressed literature can abound in psychological insight: course-members with industrial experience will recognise the businessman in the Le petit prince (1943) by St. Exupéry (1900-1944). The exhausted, anarchic cynicism of late 1940s France is nowhere better caught than in the songs of Georges Brassens (1921-1981) and other chansonniers of the time. Where did Brassens get his umbrella in Le Parapluie (The umbrella)?

J'en avais un volé sans doute, le matin même à un ami

(I had one, probably stolen from a friend, that very morning)

However, anticipating the next section of this paper, if we had used Brassens simply to evoke French 1940s zeitgeist for our students they would be missing so much. Yes, we would give them a link to the times, but they would miss his sentence balance, his exquisite choice of phrase and the 'blue flower' of romanticism that distinguishes him from the unremittlingly melancholic chansonniers of the time.

A practical reason for cross-cultural literacy and sensitivity is that our coursemembers' overseas counterparts will respond to cultivated conversation. It is well known that in some countries etiquette requires substantial general conversation before nitty-gritty business. David Beckham and Arsenal's vicissitudes won't stretch beyond the fish course. Our managers' protagonists will have benefited from a more disciplined and broader education than their British counterparts. Swathes of Europe retain the rigour and breadth of the Prussian educational tradition which imparted classical and modern literatures hand-in-hand with other arts and natural sciences to a relatively advanced level. Such managers will expect to discuss Machiavellian 
management, the advantages and dangers of iconoclasm, an existential approach to decision-making, the lessons of Plato's Republic (c428-328BCE) and the harm done to Thamesside by 1950s architecture.

\section{REFLECTIVE LEARNING}

The second motivation of the present paper is growing explicit appreciation of the importance of 'reflection and reflective learning' (Cottrell 2003). What is reflective learning it and how does literature help us to exploit its offerings? It has been widely used by health professionals (Anderson 2006; Moon 2004; Mamede 2004) and has been taken on board by educationists in our own field (Hay, Peltier and Drago 2004; Peltier, Hay and Drago 2005). The last source states:

The ability to engage in reflective thinking is important for managers, especially during periods of change. An important aim of management education is to develop this ability.

Reflective learning aims to integrate knowledge with other knowledges and to imagine future and alternative consequences. Links and connections lead to awareness of a bigger picture. Graduates must be able to consider ideas in terms of the difference these ideas make to other ideas, and not only in terms of the difference which these ideas make to the world. Accountants must be able to imaginatively address values and evolution. Peltier, Hay and Drago (2005 p. 46) argue that this runs counter to what universities have become. Universities have experienced a 'shift from a collective world in which independent and critical thought was valued, to a collective world in which the universities are expected to fulfil not these values but those of the marketplace and the economy'.

In addition to identifying links, reflective learning encourages us to bring to bear on learning the full range of our own experience and preferences. An intellectual problem's correct place is in a 'container', a melting pot of ideas, experience, knowledge and disciplinary approaches. From this will emerge, at least in the first 
instance, a direction rather than a recipe or foregone conclusion. Reflective learning invites us engage in dialogue with ourselves; to explore alternative interpretations of and answers to questions. More formally the proponents of reflective learning advocate a metacognitive stance in which we are critically aware of our own processes of mental functioning. It is a challenge to us as tutors to reward reflection and not be slaves to a 'model answer' which we might have been obliged to send to colleagues, external examiners or professional bodies.

How can literature encourage reflective thinking? Literature is shot through with questions, doubts, internal and external conflicts, dialogues and universal links. Through literature our minds are free to range across and beyond thought, time and space. Literature encourages the mind to juxtapose origins, consequences and ends.

\section{CRISIS IN HIGHER EDUCATION}

The writer's third motivation is Mary Evans' critique (2004) of the impoverished state of higher education in Britain. The economic implication of her argument is that, in our attempts to provide key 'transferable' skills which are supposedly 'useful', we may be misinterpreting the demands of the very labour market we are trying to court. The state invests less in technicians and artisans than graduates. Presumably something special is expected of them. What? Her answer echoes that given by Lord Butler four decades earlier. The labour market judges graduates on what they are rather than what they know. The marketplace is increasingly able to discern between the free-ranging, creative mind on the one hand, and the goose-stepping subject specialist on the other. But universities paradoxically still have incentives to serve an idea of a 'rational bureaucratic state of the $21^{\text {st }}$ century' which is 'a small-minded offspring of Enlightenment rationality and the market economy' (p.3).

She argues that the universities which work to a narrow over-vocational agenda are ill-serving their products. Graduates emerge into a world where cultural divisions among universities correspond to social and economic esteem in society (p. 144ff). The competition for places at Oxford, Cambridge and London is no longer about a social elite. It is about a political and cultural elite. These universities are the only 'reassuringly significant' route into the dominant culture. With Halsey (1997) and 
Bourdieu (1986) culture is for Evans a valuable commodity whose possessor can deploy and signal their possession with words and meanings.

In contemporary Britain, there is a strong case for the argument that cultural divisions are becoming more distinct, and more closely linked to the distribution of social and economic power than at any time in the history of the past one hundred years. Culture's humanitarian gloss masks its hidden power. It is the great new form of social power and the continued mask of crude social and economic power (p.148). Pedagogically the implication is that we serve our students by taking fully on board that 'education is an end in itself' (Wolf 2007). Wolf shares Evans' concern about the 'skills agenda': He says:

Understanding is a form of wealth.... Knowledge is also an end, not merely a means to some other end - a better job, a more attractive mate or...a more productive economy.

Literature is important as an end in itself as well as being a way out of increasing cultural and resulting economic disadvantage. The ancient universities of Europe had it as a large part of their purpose to promote reflective engagement with the culture, religions and professions of the society in which they were engaged (Graham 2005, Essay VII).

Rhetoric, in the Renaissance sense of poetry and other literature, was at that time considered an essential part of a university education. While not formally universities, the abbaco schools of Northern Italy, which sought to lay the intellectual foundations of mathematics and business for the merchant classes, taught Dante and Aesop along with mathematics and business. Our role as university educators today is likewise to both elevate and prepare, whatever our discipline. This ambition need not be the exclusive patrimony of the magic circle of universities, if newer universities especially in their vocational departments - become duly sensitive to the danger of becoming skills factories.

Yet even a university which successfully frees itself from a 'skills' agenda needs to remain sensitive to the peril of internecine strife and restrictiveness. Bugliarello 
(2003) points to the danger of 'atomised subcultures' in the form of interdepartmental prejudice and reciprocal ignorance: He reminds us of Sarton’s dire warning (1962) that the most ominous conflict of our time is the difference of opinion, of outlook, between, on the one side, men of letters, historians, philosophers, the socalled humanists, and on the other, the scientists.

\section{V: WHOLE USE OF LITERATURE}

The fourth motivation of the paper is the writer's concern with the way in which Badaracco (2006a; 2006b) argues that MBA students should learn literature. He uses his extensive knowledge from a range of times and cultures to identify lessons in leadership and judgment. He proceeds to apply the lessons to contemporary business and traces answers to a series of fundamental business questions (2006b, Jacket note):

* Do my deepest aspirations impel me forward through hardships, and do they engage others' aspirations and dreams?

* Will my moral code help me make the right decisions for my organization even as business conditions change?

* $\quad$ Do my role models provoke me as well as embody values I can emulate?

* $\quad$ Do I have the patience, courage, and tenacity that leadership requires?

* $\quad$ Can I set clear performance standards for myself and others - and follow through on them?

* $\quad$ Do I recognize the hidden hazards of success and the ways to avoid them?

* $\quad$ Can I make the difficult trade-offs needed to run my unit or business?

* $\quad$ Do I think through high-stakes decisions adequately despite relentless pressures on my time?

Notwithstanding the intellectual accomplishment of his analysis, it is a truncated approach to literature confined to one facet of one aspect of each work. It is limited to character analysis and emphasises only one part of each character. In so doing he misses out on a major and relevant instructive opportunity: the opportunity to impart each work as an aesthetic whole with leadership, judgement or whatever as an inseparable part of that whole. Unfortunately his truncated approach diminishes and violates the works. Hear him on the Antigone of Sophocles (496-405 BCE): 
If Sophocles teaches us that leaders cannot escape their flawed humanity, he also suggests that we can lower the risks of error and tragedy through sound reflection....As Antigone strongly suggests, the best reflection involves dialogue with others. Solitary, self-designated geniuses are a prescription for disaster.

Of course part of literature's genius is to enter the mind of the characters. But Badaracco is alluding to one part of the psychology of one of a suffocatingly entwined set of characters. And what of the magnificent poetry? What of the nature of tragedy as propounded by Aristotle? What of hubris, fate and free-will? What of the history of Greek tragedy and its influence on the whole of western literature? There is far more education in Antigone than a gouged-out vignette on leadership. Of course leadership comes in, but as part of an aesthetic whole. A work of literature is a self-sufficient, complete being with a life of its own. To teach by amputating one of its limbs is tantamount to reducing it to a glorified bullet-pointed management manual. The perpetrator is guilty of the aesthetic crime called in German zerdenken for which there is no English equivalent except the clumsy 'thinking to pieces.'

Badaracco uses Sophocles’ Antigone written 2500 years ago. Our point is better illustrated in a modern existentialist reworking of Antigone (1944) by Jean Anouilh (1910-1987). It is permeated with issues of leadership. This would please Badaracco. King Creon faces his rebellious ‘employee’ Antigone. She risks triggering an internecine Darfur by behaving heretically. Creon wearily confronts her idealistic heroic behaviour with the need to compromise in order to avoid national chaos. In similar vein Les mains sales (filthy hands) (1948) by Sartre (1905-1980) looks at the need to behave 'immorally' - to get your hands dirty - in order to keep a show on the road.

If we present these works as case studies of leadership we are depriving our students of a rich imaginative and instructive opportunity. Anouilh's Antigone and Sartre's Les mains sales are rooted in an overarching concept of an existentialist, godless, absurd cosmos in which the only meaningful behaviour is to 'say no'. Such works emerged during the upheaval of the Second World War. Half of Europe's population was being reified or eliminated as degenerate by a dictator who threatened to 
dominate the world. This context is vital to an instructive understanding of Anouilh, Sartre or Camus and many more besides.

Of equal instructive importance is Anouilh's studiedly casual language. It is depressed, laconic and a-heroic: Antigone's chorus opens the play leaning in a dinner jacket and colloquially but chillingly foretelling the fatal conclusion. There is more education, aesthetic, social and economic, in this holistic picture than in a truncated tale of leadership.

Badaracco notes that Shakespeare's Othello (c1603) is replete with themes relevant to business including race, gender, leadership, social ferment and Machiavellian behaviour. A war-hero, Othello inspires confidence and more in his Venetian command. He adapts to his seniors, juniors, private citizens and newly espoused Desdemona with consummate chivalry. But students would lose so much if the play were simply used to illustrate and discuss him as a leader interacting with the led. Villain Iago's Machiavellian materialism needs to be related to decomposition of the high ideals of the Renaissance. The new economic tempter tells the fatuous, old establishment 'gull'd Venetian gentleman' Rodrigo to succeed by 'putting money in his purse'. And what is Iago's motive? Does he literally love Othello and act out of jealousy? Is Othello’s new bride his rival? Is Othello an aging alienated man tormented by sexual self-doubt? Is it the sensual hothouse Cyprus - contrasted with civilised Venice - which provides the final and necessary setting which turns Christian leader Othello into an atavistic ritualist? And while Othello's murder of his wife is a pagan sacrifice, it has a transcendental nobility which dwarfs other characters. Then the glorious language: a handkerchief precipitates Othello's fall. Shakespeare, with the power of a machine gun, throws it at us three times in a few words (Act 3, Scene 3).

Badaracco invites us to use Death of a Salesman (1949) by Arthur Miller (1915-2005) to contrast Willy Loman's fanciful dreams with managerially efficient 'good dreams' which have their roots in daily life and 'drudgery'. Good dreams are the lesson of this play for managers. Of course it will help our students to think about this but only, to maximum intellectual benefit, in the broadest context of the play. For example is Loman a tragic hero in the literary tradition or not? If not, why not? Let students see 
how style and structure are perfectly suited to theme. Presents, pasts, realities and fantasies flow and separate in 'mobile concurrences' like the interior monologues of the stream of consciousness literature, and like the starting point of some of the most creative thinking in management. The work is an invitation to reflective thought.

All can agree with Badaracco that for a leader one of the hardest challenges is resisting the flow of success. This is indeed 'one of the most perplexing themes in literature and leadership’. Macbeth (1606) addresses Badaracco's point. But lets see how this truncated approach leads to loss of educational opportunity. Macbeth's raw, amoral ambition combats his milk of human kindness. His wife goads him. This and a succession of victories help to bring him down. So much of this is in his bitter reference to the witches: 'They met me in the day of my success' (Act 5, Scene 5). But greater questions than resisting the flow of success are asked here. The subtle interdependence between freewill and destiny transcends a simplistic illustration of 'chapters of accidents which count for so much in the book of success'. Is Macbeth a victim of fate? Are the witches' ambiguous prophesies utterances of fate toying with its victim? On the other hand did the witches merely exploit his character flaw by picking their moment? Underlying all is a transcendent question so often raised by Shakespeare. Is the universe a stable place which man with all the new science of his time can control? Or medievally is it at the whim of outside forces, be they the witches of Macbeth or the superficially cute fairies of A Midsummer Night's Dream . And we haven't even mentioned the language.

Badaracco's question about resisting the flow of success is classically addressed in Le père Goriot (1835) by Balzac (1799-1850). It contains one of the most famous quotations of French literature in its almost final words ‘à nous deux maintenant!' (It’s you versus me now!). The young hero, Eugène de Rastignac casts down the gauntlet before Paris society which he intends to conquer. The novel shows the gradual falling away of his scruples. This is necessary for his success. Compromises include serial adultery and predatory financial behaviour. But beyond such a mere 'case study’ are Balzac’s ability to bring a place to life by his extremely detailed descriptions in which not a word is wasted; and his successful portrayal of the amoral materialism of contemporary Paris. But what perhaps most transcends narrow questions of ambition, success and their drivers is Balzac's portrayal of the cosmic 
energy which, irrespective of morality, class, wealth or social position, flows through his larger-than-life heroes. Goriot is 'le Christ de la paternité' who attains sublimity in death. One of the most sympathetic characters is professional super-criminal Vautrin. Not surprisingly, Balzac was an admirer of Swedenborg (1688-1772) and Beethoven. Indeed one of his heroes whose forename is significantly César Birotteau dies to the imagined melody of the Fifth Symphony, having pulled himself up from ruin: a truly Promethean way to go. Imagine what our students would lose from stopping at a story of ambition and compromise.

The importance of appreciating a work as a whole is not intended to detract from the instructive power of detail within that whole. The Nun of the Canterbury Tales by Chaucer (c1345-1400) is an example of assertiveness and accomplished inter-personal relations - she knows how to dialogue with, adapt to and charm her fellow-pilgrims. But beyond this ‘case study' of urbane accomplishment is the choice of detail and limpid language with which Chaucer subtly suggests vanity and coquettishness beneath a pious exterior. Her cloak was of the most elegant; she was ornamented with beautiful green beads; and her shining brooch of gold bore a letter ' $A$ ' for amor vincit omnia, love conquers all! Chaucer also introduces us to the lawyer - the sergeant of the law - efficient, impressive, inspiring confidence and able to reel off centuries of case law; clearly top management material. He could be the first slide in an assertiveness course. But the interesting bit is that, in one line, Chaucer shows us his hollowness:

And yet he semed bisier than he was.

We've all met them. He resembles the much quoted example of character evocation in a short story entitled La reine Hortense by Maupassant (1850-1893):

He was a gentleman with red whiskers who always went first through a doorway 
The power of detail is sometimes captured in a momentary but eloquent change of tone-register. Jane Austen (1775-1817) devastates pomposity by this means, as does our contemporary Philip Roth (1933-).

At the other extreme from detail is the literature with a broad sweep which studies humanity and society in the form of the evolution of a character or dynasty. This is the Bildungsroman (novel of formation) tradition used by Dickens in his Great expectations as well as by Goethe and Balzac. Indeed virtually the whole of Balzac's work was inter-linked to form a massive human comedy in which all levels of society inter-acted on the stage. Less daunting than such a vast canvas but similarly instructive is The razor's edge (1944) by W.Somerset Maugham (1874-1965).

The Caucasian Chalk circle (1947) by Brecht (1898-1950) brings alive the clash among claimants on assets in times of instability, distress and social upheaval. Who should run the show? Those with a legal, biological or traditional right, or those best able to do the job? The last is the answer according to Brecht. But to discuss this without reference to his contribution to theatre would be to miss the most stimulating instructive opportunity in the play. Brecht's method is to present issues as open questions. Towards this end he tries to stop us identifying with actors' emotions. Heroine Grusche's self-sacrifice in the play is not intended to inspire sympathy. It is the act of a 'praktisch veranlagte Frau'.... a practically motivated woman. Brecht's tool is the Verfremdungseffekt, a distancing effect. Towards this end, he interpolates songs and uses a chorus who comments on the action. The same was achieved by masks in classical Greek theatre, in the middle ages and today in some Asian countries.

Preoccupation with theme at the expense of language would deprive our students of vital lessons which would help guard against some of their (and our) worst writing crimes. Few of us can cast a stone in the face of accusations of inarticulate, rambling, repetitious and jargon-ridden writing. So lend an ear to the greatest writers' quests for the original, right, word, expression, sentence and whole. Flaubert's (1821-1880) search for a single right word (mot juste) could take hours and his gift for apposite and brilliant detail has influenced literature and expression generally ever since. The discipline of poetry and in particular of a prescribed form like the sonnet can hone 
expression to economic perfection. Shakespeare's sonnets, at their best, achieve naturalness with not a single wasted syllable. One of the finest poems in European literature is only 24 words long. A child of five could understand its words. The language of poet-scientist Goethe’s Wanderers Nachtlied II (1780) is so simple and perfect as to be untranslatable. Those who have tried woefully illustrate the truth of the French proverb Qui traduit, trahit, (whoever translates betrays). The present writer's offering below is intended to deal with vocabulary not meaning.

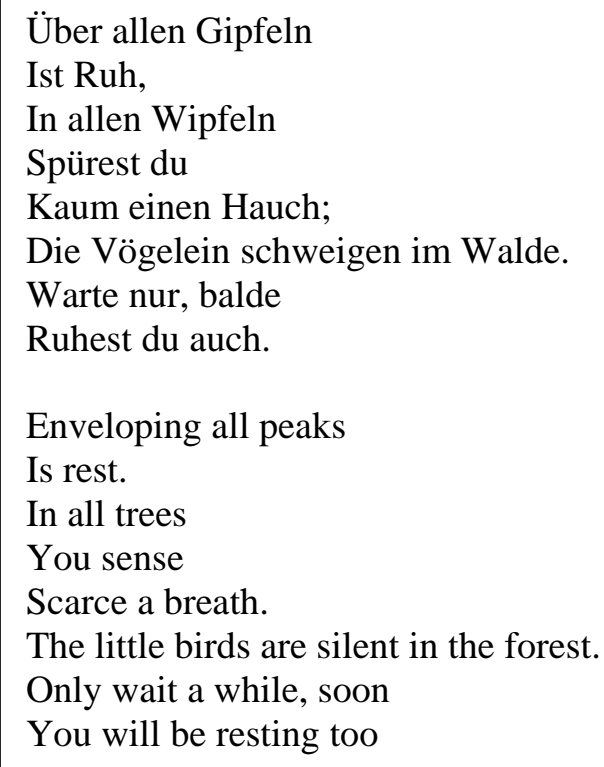

The works of Hemingway (1899-1961) such as The old man and the sea (1952) embody economy of expression, Marilynne Robinson (1943-) in her novel Gilead, (2004) with its spare, understated prose, epitomises the 'ecstatic fire' that takes things down to the essentials. The perfect sentence does not admit variations: the present writer's late tutor defined poetry as that which cannot be expressed in any other way.

None of this is intended to suggest that simple works are simplistic. Rhyme disciplines the reader's intellect. Crawford (2006 p. 7) in his interdisciplinary work on links between science and poetry says that rhyme drives in a clearly controlled acoustic direction and that if rhyme is in control of the imagination 'it constantly moves the intellectual content... in surprising and surprisingly unpredictable or barely predictable directions'. He says that poetry and science share common endeavour in 
that 'each discipline seeks a honed elegance dependent on careful pruning, leaving out, editing until only what is most needed remains'. Exposure to such expression can have far-reaching effects. Instead of opting for a tired and over-used term students of literature will recall their pleasure and surprise at writers' choice of an unusual metaphor such as abound in D.H.Lawrence’s poem like Blue gentians.

A major loss through mining literature and gouging out a message consists in ignoring the literary movements to which a work belongs. Some such movements, like postmodernism, have been predictive industrially and managerially. It is a challenging encouragement to inter-disciplinary thinking to contextualise a work in a movement which, in Jervis' words (1999, p.335), 'multiplies the margins and transitions: we all become betwixt and between, flows and circuits rather than fixed points in a moving world'.

\section{LITERATURE AS PROPHESY}

The fifth motivation: literature, the product of intelligent, senstitive and imaginative minds may be the first to pick up the scent of short, medium and long term change. Besides being of general significance, this is of specific significance to the would-be predictors of long-term required returns who do not baulk at dealing in centuries (e.g. Dimson, Marsh and Staunton (2002); Goetzmann, Ibbotson and Peng (2001)). Rates of time preference and required risk premia are bound up with anxiety, sense of stability and sense of control. Literature can capture a crucial historical moment. This can be seen as far back as Sophocles' Oedipus (c429BC) where the hero's emotions, self-discovery, gestures of freewill and independence anticipate the advancing humanism in the Greek society of his time.

Let us next picture ourselves in France at the beginning of the 1780's weighing up the chance of an upheaval. In 1784 we attend a performance of Beaumarchais' Mariage de Figaro. We wonder how the tilts at inherited wealth and privilege got past the censor. It is not surprising that Lytton Strachey, quoted in the Arnould edition (1952), lit on the following speech: 
Lytton Strachey quotes Figaro in the play:

Vous vous êtes donné la peine de naître, et rien de plus: du reste homme assez ordinaire! tandis que moi, morbleu! perdu dans la foule obscure, il m'a fallu déployer plus de science et de calculs pour subsister seulement.

You took no more than the trouble to be born; for the rest you're just more or less a common man. Not me! At sea in the crowd I've had to use more brains and tactics (than you) just to get by.

Lytton Strachey comments:

In that sentence one can hear - far off, but distinct - the flash and snap of the guillotine.

Indeed the guillotine was already audible half a century earlier in the form of the Enlightenment’s plainly subversive works. Montesquieu (1689-1755), Rousseau (1712-1778) and Voltaire (1694-1778) used reason to criticise the authoritarian state, proposing a new social order based on natural human rights including those of children. Montesquieu and Voltaire held open discussion of scepticism and atheism designed to make any monarch relying on his divine right feel distinctly insecure.

Diderot (1719-1784) in Bijoux indiscrets, published anonymously in 1748, explicitly advocated the dismantling of the establishment. His atheistic speeches took him to prison. The wide-ranging discussions which he and others generated in the salons facilitated a social mobility which was duly ominous to the regime. They spoke freely of breaking down the barriers between the knowledge of the artisan and the knowledge of the philosopher. A reader of Diderot's co-authored Encyclopédie tried to assassinate the king in 1757. The work was banned in 1759. The Sturm und Drang (storm and stress) literature of Germany around the 1770's, which represented the birth-pangs of romanticism, adumbrated upheaval.in the form of individuals challenging the state. The movement advocated attention to native, spontaneous, untrammelled Germanic folk literature at the expense of the well-behaved classics.

Charlotte Brontë's Jane Eyre (1847) powerfully anticipates the struggle for women’s rights. Two decades before the Russian revolution, Tolstoy (1817-1875) wrote the 
searing drama Resurrection (1899) whose hero reviles his inherited wealth, plans to return land to his own peasants and points out the absurd injustices dispensed to alleged criminals including children. As for the established church, an atheist character in the play addresses religious uncertainty with 'when you feel (religious) doubt have a drink.’ Maxim Gorky’s drama Enemies (1905) likewise foreshadowed a cataclysm. Written in exile and banned in Russia, it portrays a restless society whose bourgeois feel insecure and whose proletariat are squaring up to the attrition ahead.

Even earlier, the establishment of the time would have good reason to worry at how Molière, in virtually all his plays, sets common sense and the bourgeois family at the heart of social stability, rather than the church and the king with their divine right. When things go wrong in the bourgeois family, as in the very sombre comedy of avarice called L'Avare (1668) and in the lighter Bourgeois gentilhomme (1771) potentially tragic instability ensues. Even seeming idealists like Alceste in Le Misanthrope (1665) are presented as clownish automata because they rock the social boat with their wish to destabilise urbane social intercourse. Significantly Molière was writing at a time of instability in the form of the Fronde of 1648 when the king's authority was already under challenge.

Woyzeck.(1837) by Georg Büchner (1813-1837) portrays a world of unremitting misery for its brutalised proletariat. It was written decades before Karl Marx’ Das Kapital (1867) and followed years of pamphleteering in which he urged peasants to revolt. It bitterly and brilliantly portrays the reification of a self-subordinated being by the rulers. In the same writer's Dantons Tod (1835) on the death of French revolutionary Danton, clash among factions is the issue. The work was duly mauled by the censors. The 1848 upheavals were in the air.

Embodying Marx and anticipating Freud The father (1887) by Strindberg (1849-1912) shows and adumbrates marriage as nothing more sacred or blessed than economic partnership. .A more sinister instance of prophesy is Das neue Reich (The new empire) (1928) by Stefan George (1868-1933) which clearly foreshadowed the efforts of National Socialism in Germany. 
Waiting for Godot (1956) by Samuel Beckett (1906-1989) belongs to works which challenged order and conveyed a sense of bewilderment and lack of social parameters. Institutions have collapsed in Godot. Killing time, and perhaps also fellowship, are the only worthwhile activity. The victim of The trial (1925) and the creature of Metamorphosis (1915) by Kafka (1883-1924) are no less disorientated and alienated. They adumbrate a world in which traditional values have collapsed.

The 'poets of protest' like Adrienne Rich (1929-) assert that we need poetry to tell us about the reality of the past and give us the true measure of events. She struggles to give voice to this measure:

My hands are knotted in the rope And I cannot sound the bell

says Rich in her Implosions (1968). The poet is a witness and a spokesperson. The poet 'never stood a chance of standing outside history'. Poetry is 'accountable to the life of your tribe, the breath of your planet'.

At an extreme, some postmodern novels lay before us 'characters who are at once real and unreal' (Wood 2008, p. 84). As an example he refers to Savage detectives (1998) by Bolaño (1953-2003). Post-modernism is an eclectic movement which is highly relevant not least to an accountant in industry. A recent conspectus (Economist 2006) 
describes how it has influenced modern retailing including Selfridges, Virgin, Body Shop and Nike.

\section{IMPLEMENTATION}

The present proposal invites an interdisciplinary approach and this raises a number of practical issues.

With or without literature, delivery of interdisciplinary accounting is a challenge involving cross-departmental dialogue. As well as with our colleagues across the arts and social sciences we should dialogue with librarians and other informationproviders towards more thoughtful, directional advice. They would see this as a contribution to their skill as modern librarians. The library is traditionally an archive which we can use to track down a piece of information. But it is now increasingly a place where we can find out about a subject including its interdisciplinary links. This latter role should be developed through closer collaboration with subject educators.

A further issue is whether we have the right to impose literature on people who chose to major in business. The answer here submitted is yes for at least two reasons. Firstly accounting, finance and business courses, whilst being among the most vocational, are also among the most interdisciplinary. In order to be in tune with the most up to date theoretical and professional debate students must accept the need for a minimum of literacy in disciplines such as mathematics, law, behavioural sciences and obviously economics. This literacy produces the best intellectual products. The present argument has been that those products will be even better if students are exposed at an adult level and in an adult manner to literature.

A further issue is whether enough business educators are equipped to provide the suggested course. To the extent that this is not the case the proposal is an opportunity to co-operate with the arts departments of the university. The case for advancing mutual understanding was made by Bugliarello (2003) and has already been discussed. Liaison between leading poets and scientists resulted in Crawford's Contemporary poetry and contemporary science (2006) and some of the greatest brains in history, 
not least Freud, Goethe and Montaigne and Dante reached across disciplines to produce some of their finest works.

The difficulty of achieving due personal contact with students arises with every part of the curriculum. For taught postgraduates this can be less than overwhelming but where undergraduate business classes (particularly accounting) can have class sizes of several hundred students there are special problems for resourcing and deep learning. The field, its students with their personal academic needs and the very teachers are in danger of reification. One benefit of a liberal course is to help cross this bridge but the underlying difficulty of communicating to hundreds exists here as elsewhere. Properly delivered, the course will inspire discretionary reading and discussion outside the classroom. This will help to course members as a community - if matters do not become too heated, as has occasionally been the writer's experience. More happily, students might forsake some TV pap in favour of reading, listening to and viewing timeless material

We need as educators to appreciate the root and branch distinction between imparting literature, on the one hand, to young adolescents at school and, on the other, to more mature individuals. With the latter it is possible to harness towards fresh creative thinking course-members' maturing experience of lived history, culture clashes, relationships, alienation, conflicts, success, failure, decline and bereavement - to name but some of the things which resonate with maturity and which we have tried to identify in literature in this paper. The towering maturity of the emotions in Racine and Milton are wasted on the young adolescent's embryonic emotional stage. The writer recalls a despairing attempt by a teacher to impart Milton which ended in his snapping Paradise lost closed and awakening the class with a romp from Robert Burns (1759-1796).

A possible defence of Badaracco's fragmentary approach is that, although he addresses only one aspect of literature, the bit may attract students into the real thing. A second argument asserts that a crowded curriculum cannot accommodate serious study of literature beyond the recreational level. The writer submits that both these arguments are dangerous and defeatist. The danger of a single-aspect approach is to encourage a fragmentary, cafeteria attitude to literature. Concerning the second 
argument, a tutor should be able to identify sources which are as short as required but which are also microcosmic. It is furthermore certain that course-members will be happy to read some of the longer works as part of their leisure.

A scheme for fourteen weekly sessions wherein each course-member attends one presentation and one seminar might look as follows. 


\section{Literature for students of accounting, finance and business}

\begin{tabular}{|c|c|c|}
\hline Theme & $\begin{array}{c}\text { Examples of works } \\
\text { (But see Notes 2.3, and } 4 \\
\text { below) }\end{array}$ & $\begin{array}{c}\text { Example of business } \\
\text { counterpart } \\
\text { (But see Note } 1 \text { below) }\end{array}$ \\
\hline $\begin{array}{l}1 \\
\text { Special gifts of the different literary } \\
\text { genres: drama, narrative and poetry }\end{array}$ & $\begin{array}{l}\text { Initial reference to some of the } \\
\text { works to be used later }\end{array}$ & \\
\hline $\begin{array}{l}2 \\
\text { Rigour, economy and freedom of } \\
\text { expression }\end{array}$ & $\begin{array}{l}\text { Hemingway's Old man and the } \\
\text { sea; } \\
\text { Hopkins' Windhover; } \\
\text { Goethe's Wanderers Nachtlied; }\end{array}$ & $\begin{array}{l}\text { Prolix, trite, jargon- } \\
\text { ridden prose in academic, } \\
\text { professional and in-house } \\
\text { business writing }\end{array}$ \\
\hline $\begin{array}{l}3 \\
\text { Richness of meaning }\end{array}$ & $\begin{array}{l}\text { Blake’s Tyger; } \\
\text { Wallace Stevens' Thirteen ways; } \\
\text { Eliot's Prufrock. }\end{array}$ & Simplistic expression \\
\hline $\begin{array}{l}4 \\
\text { Human personality }\end{array}$ & $\begin{array}{l}\text { Character(s) in Chaucer's } \\
\text { Prologue; } \\
\text { Maugham's Razor's edge. }\end{array}$ & $\begin{array}{l}\text { Empathy in personal } \\
\text { relationships }\end{array}$ \\
\hline $\begin{array}{l}5 \\
\text { Reification }\end{array}$ & $\begin{array}{l}\text { Pynchon, Against the day } \\
\text { Büchner's Woyzeck; } \\
\text { Fritz Lang's film Metropolis. }\end{array}$ & $\begin{array}{l}\text { Danger of de-humanising } \\
\text { 'human resources' See } \\
\text { Note } 5 \text { below. }\end{array}$ \\
\hline $\begin{array}{l}6 \\
\text { Vulnerability, disorientation and } \\
\text { decline }\end{array}$ & $\begin{array}{l}\text { Miller's Death of a salesman; } \\
\text { Kafka's Trial; } \\
\text { Tony Hancock's Missing pages. }\end{array}$ & $\begin{array}{l}\text { Human impact of } \\
\text { corporate crises }\end{array}$ \\
\hline $\begin{array}{l}7 \\
\text { Alienation (tribal, class, gender and } \\
\text { other) }\end{array}$ & $\begin{array}{l}\text { McEwan' Atonement; } \\
\text { Updike's Terrorist } \\
\text { Kafka's Metamorphosis; } \\
\text { Frisch, Andorra; } \\
\text { D H Lawrence's Oxford voice; } \\
\text { Ayckbourn's If I were you. }\end{array}$ & $\begin{array}{l}\text { Cultural conflict (e.g. in } \\
\text { merger) }\end{array}$ \\
\hline $\begin{array}{l}8 \\
\text { Tolerance }\end{array}$ & $\begin{array}{l}\text { Lessing’s Nathan; } \\
\text { Lacratelle’s Silbermann; }\end{array}$ & The value of tolerance \\
\hline $\begin{array}{l}9 \\
\text { Case for reason over emotion and vice } \\
\text { versa }\end{array}$ & $\begin{array}{l}\text { Sidney Lumet's film } 12 \text { Angry } \\
\text { men. } \\
\text { Azdak in Brecht's Chalk circle }\end{array}$ & $\begin{array}{l}\text { Danger of rationalised } \\
\text { predisposition in } \\
\text { decisions }\end{array}$ \\
\hline $\begin{array}{l}10 \\
\text { Distortion of truth }\end{array}$ & $\begin{array}{l}\text { Orwell's 1984; } \\
\text { Huxley's Brave new world }\end{array}$ & Propoganda, spin \\
\hline $\begin{array}{l}11 \\
\text { Ambiguity, moral and other }\end{array}$ & $\begin{array}{l}\text { Lost, the TV series; } \\
\text { Milton's Satan in Paradise lost; }\end{array}$ & $\begin{array}{l}\text { Facile, hasty, herd- and } \\
\text { halo-driven approbation } \\
\text { and condemnation in } \\
\text { ethical decisions }\end{array}$ \\
\hline $\begin{array}{l}12 \\
\text { Conflict and compromise }\end{array}$ & $\begin{array}{l}\text { Anouilh’s Antigone; } \\
\text { Sartre's Les mains sales. }\end{array}$ & $\begin{array}{l}\text { Idealism, pragmatism, } \\
\text { reconciliation in } \\
\text { imposition of models. }\end{array}$ \\
\hline
\end{tabular}




\begin{tabular}{|l|l|l|}
\hline Table (continued) & \multicolumn{1}{|c|}{$\begin{array}{c}\text { Examples of works } \\
\text { (But see Notes 2.3, and 4 } \\
\text { below) }\end{array}$} & $\begin{array}{c}\text { Example of business } \\
\text { counterpart } \\
\text { (But see Note 1 below) }\end{array}$ \\
\hline $\begin{array}{l}13 \\
\text { Leadership }\end{array}$ & $\begin{array}{l}\text { Badaracco's Questions of } \\
\text { character; } \\
\text { Brecht's Caucasian chalk circle. }\end{array}$ & Corporate leadership \\
\hline 14 \\
Power & $\begin{array}{l}\text { Golding's Lord of the flies; } \\
\text { Barrie's Admirable Crichton; } \\
\text { Machiavelli's Prince; } \\
\text { Hobbes' Leviathan. }\end{array}$ & Exercise of power \\
\hline
\end{tabular}

\section{Note 1}

Column three indicates that each theme has one or more counterparts in business but, as stated above, this must not be pursued at the expense of presenting a work as an entity. It is entirely counter-productive to reduce a work to an amputated, bulletpointed management manual.

\section{Note 2}

Time allocated to the course will likely not exceed one lecture and one seminar weekly - seminar enrolment being broken down to groups of eight to thirteen. For this reason one work or two complementary works will be chosen for each week's focus. Formal contact hours will hopefully be supplemented by course members' reading for pleasure.

\section{Note 3}

Some of the choicest opportunities are presented by works not written in English. Except where there is a widely agreed English title, foreign titles have been used in this paper to facilitate access to translations.

\section{Note 4}

The writer is persuaded that older, timeless classics best provide instruction, perspective and context. Furthermore they tend to be less arcane, less dependent on epistemic and exegetical background, and previous knowledge. As pointed out by Bugliarello (2003) it is a fact that' the arts have become more esoteric, speaking more and more to themselves, and relinquishing, by and large, the ability to inspire or to convey a clear sense of beauty'. Wood (2008, p.2) says that Barthes (1915-1980) 'does not write as if he expects to be read and comprehended by any kind of common reader'. On the other hand, some educators may prefer to include more contemporary works. The writer has therefore tried to include apposite references in the table and throughout the paper.

\section{Note 5}

Study of the humanities guards against the danger pointed out by Joseph Butler (1756) of oversimplifying people into 'monominded egoists who populate the state of nature in Hobbes' Leviathan with its crude account of human motivation.' 


\section{CONCLUSION}

Literature can make a multifaceted contribution to educating our accountants whether in professional practice, the public service or industry. Literature reinforces original, creative, imaginative and multicultural thought. By adding a disciplinary dimension it encourages reflective consideration of ideas in terms of the difference which they make to other ideas. It militates against the threat of de-disciplining in one of the most vocational areas in the whole university curriculum. Studied holistically, it sets important issues of management into the context of human endeavour and choices. Not least literature is prophetic. These benefits are strengthened by literature's ability to expose its readers and listeners to some of the most concise, articulate, powerful and sensitive expression ever uttered. The labour market will in the long run penalise those who lack the qualities which can be uniquely imparted by literature. If we deny literature to our students they will be the poorer: no flowers will mean no gold. 


\section{REFERENCES}

Anderson, Chris (2006) The long tail: why the future of business is selling less of more (New York NY: Hyperion).

Anderson, Claire (2006) Introduction, Pharmacy education, 6, 3, 215-228.

Anouilh, J. Antigone. Published 2005 (Paris: Table ronde).

Ayckbourn, A. (2006) If I were you. This work had not yet been published at the time of writing.

Badaracco, J.L., Jr. (2006a) Leadership in literature, Harvard business review, 84, 3, 47-55.

Badaracco, J.L., Jr. (2006b) Questions of character (Boston MA: Harvard Business School Press).

Balzac, H. de, Le pere Goriot. Translated by Krailsheimer, A.J. 1999 (Oxford: Oxford University Press).

Barrie, J.M. The admirable Crichton. Published 1984 (London: Hodder and Stoughton).

Beaumarchais, P. Le mariage de Figaro. Edited by Arnould, E.J. 1952 (Oxford: Blackwell). 
Beckett, S. Waiting for Godot, Published 2006 (London: Faber and Faber).

Blake, W. Songs of innocence and experience: shewing the two contrary states of the human soul. Published 1970 (Oxford: Oxford University Press).

Bolano, R. The savage detectives. Published 2007 (London: Picador).

Bourdieu, P. (1986) Distinction: a social critique of the judgement of taste (London: Routledge).

Brecht, B. The Caucasian chalk circle. Published 2007 (London: Penguin).

Büchner, G. Woyzeck. Published as Danton’s death, Leonce and Lena, Woyzeck, 2008 (Oxford: Oxford University Press).

Bugliarello, G. (2003) A New trivium and quadrivium, Bulletin of science, technology and society, 23, 106-113.

Burns, R. Published 1994 as The collected poems (Ware: Wordsworth).

Burnside, J. (2006) A science of belonging: poetry as ecology, in Crawford, R. (ed.) Contemporary poetry and contemporary science (Oxford: Oxford University Press).

Butler, J. Five sermons. Edited by Darwell, S.J. 1983 (Indianapolis: Hackett Publishing).

Chaucer, G. The Canterbury tales. Translated by Coghill, N. 2003 (London: Penguin).

Cheng, T-Y. (1993) Is Chinese thought pattern linear circular or both, Working paper (Muncie IN: Ball State University).

Chrétien de Troyes. Yvain. Translated by Raffel, B. 1987 (Newhaven CT: Yale University Press). 
Coetzee, J.M. (2003) Elizabeth Costello (London: Secker and Warburg).

Cottrell, S. (2003) Skills for success: the personal development planning handbook (Basingstoke: Palgrave Macmillan).

Crawford, R. (ed.) (2006) Contemporary poetry and contemporary science (Oxford: Oxford University Press).

Dante, The divine comedy. Translated by Sisson, C.H. 1992 (Oxford: Oxford University Press).

Da Silva, S., Matsushita, R., Gleria, I. and Figueiredo, A (2006) International finance from macroeconomics to econophysics (Commack, NY: Nova Science).

Dickens, C. Great expectations. Published 1992 (Ware: Wordsworth).

Diderot, D. Les bijoux indiscrets. Published 1997 (Paris: Bookking International).

Dimson, E, Marsh, P. and Staunton, M. (2002) Triumph of the optimists 101 years of global investment returns. (Princeton NJ: Princeton University Press).

Economist. (2006) Post-modernism is the new black, 23 December.

Eliot, T.S. Prufrock and other poems, Published 2007 (West Valley City UT: Walking Lion Press).

Evans, M. (2004) Killing thinking (London : Continuum).

Frisch, M. Andorra. Published in English 2001 (London: Methuen).

George, S. (1928) Das neue Reich, (Berlin: Bondi).

Gertsen, M.C., Søderberg, A-M. and Torp, J.E. (1998) Cultural dimensions of international mergers and acquisitions (Berlin: de Gruyter).. 
Goethe, J.W. von, Faust. Translated by Williams, J.R. 2007 (Ware: Wordsworth).

Goethe, J.W. von, Selected poems. Translated by Whaley, J. 2000 (London: Dent).

Gorky, M. Five plays. Published 1988 (London: Methuen).

Goetzmann, W.N., Ibbotson, R.G. and Peng, L. (2001) A new historical database for the NYSE 1815 to 1925: performance and predictability, Journal of financial markets, 4, 1-32.

Golding, L .(1962) Lord of the flies (New York: Coward-McCann)

Graham, G. (2005) The institution of intellectual values (Exeter: Imprint Academic).

Halsey, A.H., Lauder, H., Brown, P. and Stuart Wells, A.(eds.) (1997) Education:

culture, economy, society. (Oxford: Oxford University Press).

Hardy, T. Tess of the D'Urbervilles. Published 2005 (Oxford: Oxford University Press).

Hemingway, E. The old man and the sea, Published 2006 (London: Picador).

Hay, A., Peltier, J.W. and Drago, W.A. (2004) Reflective learning and on-line management education: a comparison of traditional and on-line MBA students, Strategic change, 13, 4, 169-182.

Huxley, A. Brave new world. Published 1946 (London: Harper)

Hayes, N.K. (ed.) (1991) Chaos and order: complex dynamics in literature and science (Chicago: University of Chicago Press).

Hobbes, T. Leviathan. Published 1998 (Oxford: Oxford University Press). 
Holub, M. (2006) Rampage, or science in poetry, in Crawford, R. (ed.) Contemporary poetry and contemporary science (Oxford: Oxford University Press).

Hopkins, G.M. Selected poetry, Published 1998 (Oxford: Oxford University Press).

Housman, A.E. The collected poems of A.E. Housman. Published 2005 (Ware: Wordsworth).

Kafka, F. The trial. Published 1957 (New York: Knopf).

Kafka, F. The metamorphosis. Published 1996 (Mineola NY: Dover Publications).

Lacratelle, J. de, Silbermann. Translated by Marx, H. 2004 (New York: Helen Marx Books).

Lawrence, D.H. Lady Chatterley’s lover. Published 2005 (Ware: Wordsworth).

Lawrence, D.H. The complete poems. Published 2005 (Ware: Wordsworth).

Le Carré, J. (1999) The spy who came in from the cold (London: Spectre).

Lessing, G.E. Nathan the wise. Published 1972 (Woodbury NY: Barron's Educational Series).

Lister, R.J. (2005) Cost of capital: the case for the prosecution, Investment management and financial innovations, 2/2005, 142-157.

Machiavelli, N. The prince. Published 2004 (London: Penguin).

Mamede, S. and Schmidt, H.G. (2004) The structure of reflective practice in medicine, Medical Education, 38, 12, 1302-1308.

Maugham, W.S. The razor's edge. Published 1992 (London: Penguin). 
Maupassant, G. de, Best short stories, Bilingual edition, 1996 (Ware: Wordsworth).

McEwan, I. (2001) Atonement (London: Jonathan Cape).

Melville, H. Bartleby, the scrivener, Published 2006 (Oxford: Dodo Press).

Miller, A. Death of a salesman. Published 2000 (London: Penguin).

Milton, J. Paradise lost. Published 2003 (London: Penguin).

Molière, Tartuffe. Translated by Wood, J. and published in “The Misanthrope” and other plays, 2000 (London: Penguin).

Moon, J. (2004) Using reflective learning to improve the impact of short courses and workshops, Journal of continuing education in the health professions, 24, 1, 4-11.

Orwell, G. The complete novels. Published 2000 (London: Penguin).

Peltier, J.W. , Hay, A., and Drago, W.A. (2005) The reflective learning continuum: reflecting on reflection, Journal of marketing education, 27, 3, 250-263.

Peterson, R. (2005) The neuroscience of investing: FMRI of the reward system, Report (San Fransisco CA: Market Psychology Consulting).

Plato, The republic. Translated by Lane, M. and Lee, H.D.P. 2007 (London: Penguin).

Post, T. and Levy, H. (2005) Does risk seeking drive stock prices? A stochastic dominance analysis of aggregate investor preferences and beliefs, Review of financial studies, 18, 3, 925-953.

Prevost, A-F. Manon Lescaut. Published as Histoire du Chevalier des Grieux et de Manon Lescaut. 1967 (Paris : Garnier-Flammarion).

Pynchon, T.H. (2006) Against the day (London: Vintage). 
Rich, A. (1993) Adrienne Rich's poetry and prose (New York: Norton)

Robinson, M. (2006) Gilead (London : Virago).

Saint-Exupery, A. de (1943) Le petit prince (Marrickville NSW : Harcourt Australia).

Sarton, G. (1962) The history of science and the new humanism (with recollections and reflections by Robert K. Merton). Published 1998 (New Brunswick: Transition Books).

Sartre, J-P, Les mains sales. Published 1985 (London: Methuen).

Schiller, F. von, Über naive und sentimentalische Dichtung. Published 2002

(Ditzingen: Reclam).

Sophocles, The three Theban Plays: 'Antigone', 'Oedipus the King', 'Oedipus at Colonus' (London: Penguin).

Sterling R. (1971), Asset valuation and income determination (Houston TX: Scholars Book Co).

Stevens, W. The emperor of ice-cream. Published in The emperor of ice-cream and other poems 2005 (Mineola NY: Dover Publications).

Stoppard, T. Rosencrantz and Guildenstern are dead. Published 1973 (London: Faber and Faber).

Strindberg, A. The father. Translated by Oland, E. and W. 2003 (Mineola NY: Dover).

Tienari, J., Søderberg, A-M., Holgersson, C. and Vaara, E. (2005) Gender and national identity constructions in the cross-border merger context, Gender, work and organization, 12, 3, 217-241. 
Tirole, J. (2006) The theory of corporate finance (Princeton NJ: Princeton University Press).

Tolstoy, L. Resurrection. Translated by Maude, L. 1999 (Oxford: Oxford University Press)

Tolstoy, L. War and peace. Translated by Pevear, R. and Volokhonsky, L. 2006 (London: Penguin).

Updike, J. (2006) Terrorist (London: Penguin).

Verlaine, P. Published as Paul Verlaine selected poems, bilingual edition translated by Sorrell, M. 1999 (Oxford: Oxford University Press).

Weinstein A. (1995) Literature and life, a series of recorded lectures (Chantilly VA: The Teaching Company).

Weinstein A. (2003) A scream goes through the house (New York NY: Random House).

Wolf, M. (2007) Education is a worthwhile end in itself, Financial times, 2 February.

Wood, J. (2008) How fiction works (London: Jonathan Cape). 